\title{
DECOLONISATION OF THE LAW CURRICULUM IN SOUTH AFRICA THROUGH THE PRISM OF A LIVED EXPERIENCE
}

\author{
by Mandisi Magula* \& Shatadi Phoshoko**
}
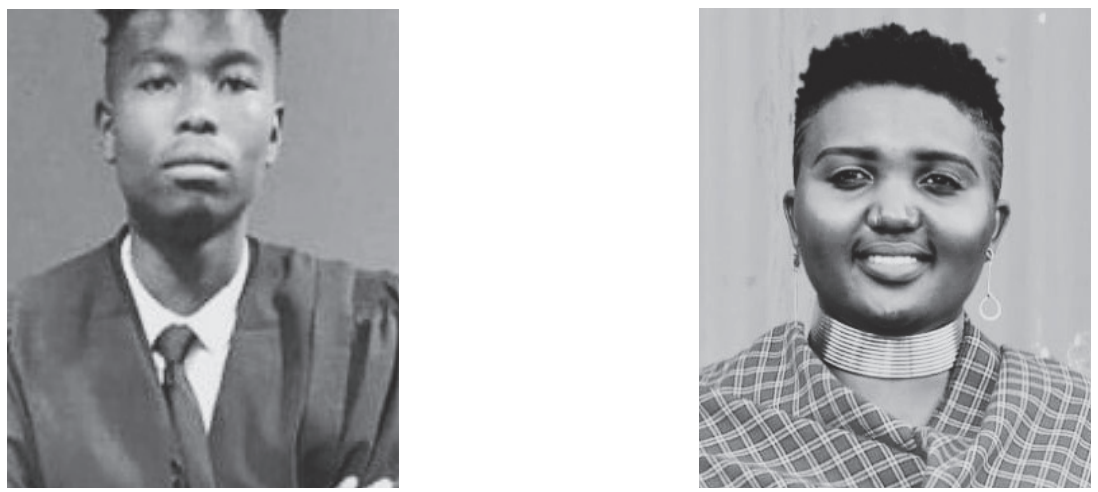

\section{Abstract}

The current educational system, with a specific focus on legal education, remains based on Eurocentric knowledge with only limited inclusion of African knowledge. The article examines the historical context and the negative impact of colonial legislation on the law curriculum. The biggest problem identified in the law curriculum is that most modules (delete contents) and programmes are not linked to African cultures, realities and do not seek to address or solve African problems. This article argues for the creation of an Afrocentric law curriculum and the development of sufficiently rigorous local knowledge that relates better to the needs of students and the challenges in South Africa, while at the same time contributing to global knowledge production. This will make schools of law produce lawyers who are skilled to solve the problems confronting African people from different cultures. This article proposes solutions on how to decolonise, Africanise and transform the law curriculum.

* LLB Candidate, University of South Africa.

** LLB Candidate, University of South Africa \& Secretary General of Unisa Law Students Association (ULSA). 


\section{Introduction}

The lecture room-based education system was introduced and designed by the Dutch in the 1700s. The curriculum only covered Western knowledge, and that has been maintained over the years with minor inclusions of African knowledge systems. However, this has done nothing to dismantle the Eurocentrism embedded in the curricula. ${ }^{1}$ Most modules in the law curriculum are not linked to African cultures and realities and do not seek to address or solve African problems. Examples of African problems include economic crimes such as theft and succession in traditional marriages.

There needs to be a proper re-look into the law curriculum, accompanied by change and reconstruction that will see the overthrow of colonial education and the inception of an Afrocentric law curriculum. ${ }^{2}$ A colonised curriculum focuses on Western knowledge systems and either ignores or makes very small inclusions of African knowledge systems. ${ }^{3}$ As such, it is important to develop sufficiently rigorous local knowledge that relates better to the needs of students and challenges in South Africa, while contributing to global knowledge production from the perspective of Africa. ${ }^{4}$ This will make schools of law produce lawyers who are skilled in solving problems confronting African people. Moreover, it will rectify the Western idea that knowledge is produced from the west and can only be accepted based on that. ${ }^{5}$

The law curriculum plays a pivotal role in deciding the direction of the country. The content of the legal education imparted on students shapes them into future law practitioners who are tasked with one of the most pivotal roles of ensuring that the law works for its citizens. The problem, however, is the heavy reliance on Western culture, language and ideology and the cognitive dominance that creates self-doubt for Africans, and the over glorification of everything Western. This article demonstrates the historical context of colonialism in the law curriculum and laws that were passed in that regard. While highlighting the issue of language, as well as problems

1 The term Eurocentrism refers to 'the discourse that emphasizes European concerns, culture, history and values as superior at the expense of others'; $S$ Makrinius \& B Rebel 'Eurocentric or Afrocentric? A case study on the South African curriculum in Humanities' https://dspace.library.uu.nl/bitstream/ handle/1874/34385 (accessed 24 April 2019).

2 The term 'Afrocentric' means 'content that is centred around African traditions, culture and history'; WD Mignolo 'The rhetoric of modernity, the logic of coloniality and grammar of de-coloniality' (2007) 40 Culturalstudies 20.

$3 \mathrm{~J}$ Evans 'What is decolonized education?' http://m.news24.com.SouthAfrica/ News/what-is-decolonized-education-20160925 (accessed 25 April 2019).

4 SJ Ndlovu-Gatsheni 'The Dynamics of epistemological decolonization in the 21st century: towards Epistemic freedom' (2018) 40 Strategic Review of South Africa 24.

50 Imbo An introduction to African Philosophy (1998) 34. 
associated with the curriculum, it concludes by proposing solutions on how to decolonise, ${ }^{6}$ Africanise, ${ }^{7}$ and transform the law curriculum.

\section{Historical context of colonisation of the law curriculum}

South Africa's legal system is referred to as a hybrid or mixed legal system owing to a few legal traditions that influence it. These include Roman-Dutch law, common law, English law and customary law. ${ }^{8}$ Three of the four legal systems, excluding customary law, are a representation of colonialism. ${ }^{9}$

\subsection{The Dutch's education system design}

An argument may arise that education and the law have existed since before the white settlers arrived in South Africa. But it remains a factual point that schools were established formally by the Dutch in the late 1700 s. $^{10}$ This is one of the many reasons why Christianity, which is another foreign belief system to the African people, is so deeply embedded in the legal system. This is because when the Dutch arrived in South Africa, they also had a plan to convert Africans into Christians for reasons that would benefit them. Therefore, the curriculum they implemented in the 1700s was centred on Christianity. The project of the colonialists continued during the apartheid era to convert Africans to Christians. Equally, curriculum content cannot exist without language.

\subsection{Afrikaans as a language}

Afrikaans is a diluted version of Dutch because it had been in contact with African languages that were adopted by the Afrikaner in colonial times. ${ }^{11}$ Realising that they are now detached from the Dutch, the

6 The term decolonisation is described as the process of working toward a vision of human life that is not structured by the forced imposition of one ideal of society over those who differ; Mignolo (n 2 above) 449.

7 'Africanisation' is a process of inseminating African value systems, concepts and moral ethics into all human activities where people are acting freely to create their own future and are liberated from the mental passivity in which they have been imprisoned by colonialism; DK Koka The impact of Eurocentric system of Education on the Afrikan mind: Decolonizing the mind (1996) 54.

8 A Bauling 'Historical foundations of South African Law' University of South Africa (2017); HFL 1501 Tutorial letter 501 (2017) University of South Africa

9 Colonialism refers to the practice of acquiring full political and social control over another country by settlers or colonialists thereby exploiting it economically; J Rossouw 'South Africa's enduring colonial nature and universities' (2018) 40 Strategic Review for Southern Africa 65.

10 Bauling (n 8 above) 8.

11 XS Ntombela The double-edged sword: African languages under siege (2004) 12. 
Afrikaners established themselves as a nation through the instrumentality of a language of their own. ${ }^{12}$ What the Afrikaners did to legitimise the language, was to champion the use of Afrikaans in government by making Afrikaans a legal medium of instruction in politics, commerce and the judiciary in 1948 with the instigation of Apartheid. In the educational system, Afrikaans was enforced as the medium of instruction in schools. Early resistance to this development is well documented. For instance, it caused the Soweto uprising of 1976 when learners fought for the removal of Afrikaans as a medium of instruction in schools because it disadvantaged them. ${ }^{13}$ Yet, as a lived experienced, one still experiences question papers of examinations still comprising of both English and Afrikaans in post1994 South Africa.

\section{The impact of legislation on the law curriculum}

The impact of apartheid legislation is discernible from a number of legislation passed in that era, some of which are still extant in South Africa. A number of such legislation are described below.

\subsection{The British Colonial Laws Validity Acts 28 \& 29 of 1865}

This Act provided that there would be no competition to or defying of any colonial laws. ${ }^{14}$ One hundred and fifty four years later, the British or English legal traditions are still the most used in procedural aspects of the South African legal system and methods of adjudication. For instance, in 1828 the Criminal Procedure Act was passed, thereby introducing criminal laws which were substantially modelled on those of the English system. ${ }^{15}$ The English system continues to be a part of our legal system, after having been introduced by the colonialists in South Africa.

\subsection{The Educations Proclamation Act 55 of 1921 and the amended Education Proclamation Act 16 of 1926}

In 1921 the Educations Proclamation Act was passed, making provisions for necessary funds for the management of non-white education by mission societies, provided that they would conform to government regulations. ${ }^{16}$ This Act was however superseded by the

12 Ntombela (n 11 above) 167.

13 E Ukam 'The choice of language for African Creative Writers' 7 English linguistics research: Sciedu Press 2.

14 The British Colonial Laws Validity Acts 28 \& 29 of 1865.

15 Criminal Procedure Act 40 of 1828.

16 Education Proclamation Act 55 of 1921. 
Education Proclamation Act 16 of 1926, which continued the government's control and management of all education. ${ }^{17}$ These Acts played a pivotal role in intensifying colonial education and ensuring that the education dispensed to the African student did not serve him or her or the community he/she comes from.

\subsection{The Bantu Education Act 47 of 1953}

In 1948 when the Nationalist Government came into power, they introduced the Bantu Education Act whose aim was to legalise and intensify apartheid in schools. This saw movements such as the 1976 student uprising where students revolted against the Bantu education system due to its anti-Africa pro-European status. ${ }^{18}$ However, the other purpose of Bantu education was to equip black students with skills for general work at factories, farms and companies due to demand for such workers in those fields.

\subsection{The Extension of the University Act 45 of 1959}

In 1959 the Bantu education curriculum was extended to 'non-white' universities and colleges with the Extension of Universities Act of 1959 which made provision for separate universities for separate race groups. ${ }^{19}$ These aforementioned laws have played a pivotal role in the destruction of quality education.

\subsection{Post-1994 development}

Post-1994, when a black government under the leadership of the African National Congress (ANC) came into power, changes were made when legislation such as the Extension of the Universities Act of 1959 and the Bantu Education Act 47 of 1953 were repealed. The government started working on the restructuring of the universities through mergers and incorporations, thereby allowing both black and white students to learn in the same institutions. Yet the problem is far from being completely addressed. For instance, during the 2016 fees must fall protest when students demanded a free decolonised education, a University of Cape Town student leader, Athabile Nonxuba, in an interview with News24 highlighted the challenge by commenting as follows:

Our own thinking as Africans has been undermined. We must have our own education from our own continent. The current curriculum does not

17 Education Proclamation Act 16 of 1926.

18 T Karis \& GM Gerhart 'From protest to challenge' (1997) 1 Standford University, Hoover Institution Press 567.

19 The Extension of the University Act 45 of 1959. 
accommodate African knowledge systems and expression in African languages. ${ }^{20}$

Arguably, the reason behind these problems being raised by Athabile Nonxuba is due to the fact that South Africa education has been colonised. As Credo Mutwa further observes, ${ }^{21}$

writers and researchers deliberately overlook many important facts about African people and sometimes go out of their way to deliberately merely skim the surface of African knowledge and overlook the rest then pass on to nations and races they favour. ${ }^{22}$

\section{Problems related to a colonised law curriculum}

The biggest problem identified in the law curriculum is that most modules or programmes are not linked to African cultures and realities, and African languages are side-lined while languages that were imposed on Africans take priority. Imposing a foreign language and suppressing native languages seeks to dismantle the harmonious connection between Africans and their culture and place in the world. ${ }^{23}$ This had a ripple effect on African children because of the lack of a harmonious connection between the language that was spoken at home and the language as taught in the institution.

Decolonising the law curriculum would mean using methodologies and learning materials that disrupt Eurocentric hegemonies. A colonised curriculum impedes access to the full range of knowledge and it prevents free inquiry and the search for truth. 24

Through this curriculum, students are expected to gain skills and Eurocentric knowledge that will allow them to enter the marketplace. However, the quality of such education rarely allows them to make fundamental changes to the status quo in the society. ${ }^{25}$ Perhaps the problem is that there exists a view that Afrocentric knowledge is difficult to package into academic material. There has been multiple attempts to justify and explain this, including the argument that the African knowledge is unwritten, hence, its merit as a system is weak. This claim does not lack entire merit in that it is said to be quite difficult to record African knowledge in academic books as African

\footnotetext{
Evans (n 3).

C Mutwa Africa's hidden history: The reptilian agenda (1964) 11. As above.

Ngũgĩ Wa Thiong'o Decolonising the Mind: The Politics of Language in African Literature (1986) 29.

24 Evans (n 3 above).

25 S Heleta 'Coloniality persists in our universities and we must urgently decolonize' https://mg.co.za/article/2016-11-18-00-coloniality-persists-in-our-universitiesand-we-must-urgently-decolonize (accessed 07 July 2019).
} 
knowledge is regarded as non-scientific and undermined. ${ }^{26}$ This reality explains why African knowledge is largely excluded from the curriculum. Hence, South African universities continue to produce law students every year who lack the required skill set to solve African people's problems. It is so because the current legal system does not recognise and address experiences of African people, especially indigenous people. Largely Eurocentric, the law curriculum has made students blind to the identity and knowledge of their country and the people who live in it. When addressing colonialism in the education system, Credo Mutwa had this to say;

The black man of South Africa must be denied his identity to make it easier for people with sinister agendas to turn him into a puppet, spiritually and physically dependent on the west and its exploitative ways. The black man must be made to look down upon himself and other nations must be made to look down on him too. ${ }^{27}$

The erasure and selective inclusion of African knowledge in the curriculum creates a situation where African people are entirely undermined and not taken seriously, while Eurocentric knowledge systems are advanced and widely occupy our curriculum. The colonised curriculum in South Africa has promoted white supremacy and stereotyping of Africa. ${ }^{28}$ The current curriculum, ${ }^{29}$ still largely reflects colonial worldviews and is disconnected from African realities, including lived experiences of the majority of black South Africans. 30

\section{Decolonising and Africanising the law curriculum}

Decolonisation of knowledge presents at least the conceptual possibility of decoloniality of power. ${ }^{31}$ There are universities whose law curriculum have been improved, such as the law curriculum of University of South Africa (UNISA) which comprises modules like

26 E Mkhwanazi Introduction to African philosophy (2018) Study Guide for PLS 1502 University of South Africa) 9.

27 Mutwa (n 21 above) 11.

28 White supremacy is a system that maintains the ideology that white people are superior over the other races thereby marginalising them. M Christian 'An African centred perspective on white supremacy' 332 Journal of black studies 179.

29 Constitutional law, Criminal law and civil procedure, amongst other modules, reflect the British colonial laws.

30 Heleta (n 25 above).

31 Decoloniality is the process that seeks to promote the doing away of colonialism legacies; D Mashau 'Unshackling the chains of coloniality: Re-imagining decoloniality, Africanisation and reformation for a non-racial South Africa' 74 Theological studies 2-3. 
Language through an African lens, Introduction to African Philosophy and African Customary Law. ${ }^{32}$

\subsection{Creation of an Afrocentric curriculum}

Firstly, there needs to be a radical change of content in the law curriculum so as to create an Afrocentric law curriculum. Of importance here is to develop sufficiently rigorous local knowledge that relates better to the needs of students and the challenges in South Africa, while contributing to global knowledge production from the perspective of Africa. It is noteworthy too, that eurocentrism does not only mean affirming and centralising European knowledge, but includes the appropriation of other people's knowledge and erasing their contribution. ${ }^{33}$

As South Africa's curriculum requires students to read primary sources, particularly court decisions, in order to acquire and appropriate the conventions of academic and legal discourse, this must translate into practice. The curriculum needs to produce relevant knowledge that is effective and empowering for the people of the African continent, especially the immediate African societies the universities serve. In an attempt to outline the importance of an Africanised curriculum, Nkoane notes:

Africanised education maintains African awareness of the social order and rules by which culture evolves; fosters the understanding of African consciousness; facilitates a critical emancipatory approach to solve the problems of their lives; and produces the material and capacities for Africans to determine their own future. ${ }^{34}$

\subsection{Pedagogy and epistemological decolonisation and Africanisation of the curriculum}

Secondly, there should be a focus on pedagogy, which is the method and practice of teaching. There is a need to change not only what is taught but how it is taught too. ${ }^{35}$ Currently, the method of teaching follows a banking system, where students cannot analyse, question and reject certain information from the study material. As such, students are reduced to receivers of information. Hence, the way in which content is dispersed to students must be transformed.

32 The module 'African philosophy' is a module that introduces students to metaphysical epistemological, ethical and political problems about the nature of African philosophy. And the module 'African customary law' involves equipping students with valuable knowledge and skills as well as competencies to enable them to analyse legal material directly pertaining to customary law.

33 J Baba 'William Mpofu at NWU Vaal on Decolonization of the curriculum P1'. https://m.youtube.com/watch?v=Vlw9Dmysmo (accessed 13 May 2019).

34 CHE A proposal for undergraduate curriculum reform, Pretoria.

35 P Freire Pedagogy of the oppressed (1970) 43. 
Transformation here would mean moving away from the thought that the curriculum is something that is merely received, but rather as something that is a co-constructed set of understandings. ${ }^{36}$ Transformation, however, is not only limited to changing how the curriculum is taught, but further expands to systematic change to the curriculum, such as introducing an extended curriculum across the board.

This is a necessary precondition for achieving the goals of equity of access and equity of outcome. The recent report of the Council of Higher Education outlined a lack of critical thinking as one of the problems related to current legal education. ${ }^{37}$ Whilst this may be the case, the key focus should be what content students are expected to think critically about. If the knowledge they receive in academia is not in sync with their lived experience then even their critical thinking will contradict the curriculum. Hence, students' critical thinking should include how to facilitate the rule of law to deepen economic development, human rights and human dignity so as to foster problem solving skills.

There is also the need for an epistemological decolonisation of the curriculum. There is an important epistemological argument made by Ndlovu-Gatsheni. According to the author;

the historicity of the human condition, whereby we are born into preexisting conversations regarding our pasts and our presents, necessarily shapes the positions from where we think and argue. ${ }^{38}$

The implication of this argument is that colonisation of the curriculum has had negative long term effects on African knowledge, education and social theory. Hence, the need to embark on a deliberate and radical journey to ensure that the curriculum is decolonised so that the education received can be to both student and societal benefits. Students are confronted by texts and theories that negate their own history and lived experiences in the current law curriculum. It is thus important that legal education is situated in African epistemologies and knowledge production, interpreting existing bodies of knowledge and providing cognitive justice. ${ }^{39}$ This will make schools of law produce lawyers who are skilled in solving problems confronting African people. Moreover, it will destroy the idea perpetuated in the curriculum by western knowledge that knowledge is only produced in the west.

36 W Ngcaweni \& B Ngcaweni We are no longer at ease (2015) 25

37 CHE The state of the provision of the Bachelor of Laws (LLB) qualification in South Africa, Pretoria

38 Ndlovu-Gatsheni (n 4 above) 9.

39 Motshabi B Decolonizing the university: A Law perspective (2018) 40 (1) Strategic review for Southern Africa 112. 


\subsection{Prioritisation and development of African languages}

There must be an inclusion of African languages in the curriculum such as in the question papers and tutorial letters. Furthermore, it is recommended that universities follow the University of KwaZuluNatal in this regard, where students are required to complete at least one module in an African language to complete their degree. The module must however be related to law on all accords. Language is not only a medium of instruction, it can be defined as a system of arbitrary vocal symbols by means of which the members of a society interact in terms of their total cultures. ${ }^{40}$

A decolonised curriculum must place South Africa at the centre of teaching, learning and research, and incorporate the epistemic perspectives, knowledge and thinking from the African continent and place them on an equal footing with the currently hegemonic Eurocentric canon. ${ }^{41}$ The legal system must be seen as a core component which shapes the social and economic fabric of society. Law students should be educated to view law through this broader prism. ${ }^{42}$ Furthermore, decolonising the law curriculum does not mean complete the erasure of all legal knowledge currently captured into the law curriculum, however, it means interpreting some of it from an African perspective. According to Savo Heleta, decolonisation of the curriculum also entails 'linking colonial and discriminatory legacies to the here and now', which in South Africa continues to be an ever present reality for many. ${ }^{43}$

Below are examples on how the law curriculum may be decolonised by the creation of an Afrocentric law curriculum. Although there are several modules, the point will be illustrated by reference to four modules, namely, Customary Law, International Law, Criminal Law and Law through ubuntu.

\subsubsection{Customary Law}

Modules such as African Customary law that attempts to address African problems, are covered with distortion and misrepresentation of the African people and their experiences. These include statements such as only Khoi-sans are the rightful original inhabitants of South Africa, implying that other South Africans are foreign to South Africa. These modules must be written and taught critically from the perspective of African people and be on the same standard as the

40 Ukam (n 13 above) 46.

41 Heleta (n 25 above).

42 Dennis Davis 'Legal transformation and legal education: congruence or conflict?' (2015) 1 Acta Juridica 172-188.

43 Heleta(n 25 above). 
other legal modules as opposed to subjugating it and placing it as "the other module". ${ }^{44}$

\subsubsection{International Law}

International law has been criticised for masking Eurocentric traditions or ways of doing things as universal principles. ${ }^{45}$ As a body of rules regulating various global interactions, it needs to be inclusive of Afrocentric principles too. As such, the teaching of international law in the law curriculum should provide critical discussion around important epistemologies that emerged from diplomatic interactions between and among pre-colonial African empires on state building, peace, security and negotiations, methods of trade and dispute settlement mechanisms that were used. ${ }^{46}$ African perspectives and knowledge contribution to international law has been written off as primitive, thereby side-lining these over Eurocentric principles.

\subsubsection{Criminal Law}

It is clear that Criminal law is inclusive of how crimes were resolved in pre-colonial times, and crime and punishments should be written from the perspective of the African people. Moreover, it is necessary to teach with scenarios that resonate with the everyday experience of the South African student, so as to equip the student with the skills of solving problems that confront the people in the society. Case laws in criminal law must be inclusive of land claims cases, racism and crimen injuria cases and customary law cases.

\subsubsection{Law through ubuntu}

Ubuntu is a crucial part of South Africa's traditional epistemology. Its inclusion in the curriculum shows that ubuntu forms a very crucial part of our law. However, whilst students are taught about ubuntu, they are not taught how to apply it in the legal practice. As Ramose observes:

Ubuntu may be seen as the basis of African law ... It is the experience of nonequilibrium that is thus the basic problem of law. To solve this problem, law invokes the concept of order as the means to establish and maintain equilibrium in human relations. Justice may be regarded as the affirmation of the view that order cannot come of chaos or lawlessness. ${ }^{47}$

44 Heleta (n 25 above).

45 F Babatunde 'Some thoughts on centering Pan-African Epistemic in the teaching of public international law in African Universities' (2019) 21 International Community Law Review 171.

46 As above.

47 B Ramose African philosophy through Ubuntu (1999) 79. 
In essence, the law's purpose is to instil order within human relations, as such, it should have the characteristic of solving problems, relations and interactions more than the character of punishing the other human being. The law needs to be taught from an African perspective, of which the basic principle is ubuntu.

\section{Conclusion}

Direct colonialism may have ended in South Africa, however, its legacies in different spheres of our lives such as in the education system continue. It is for this reason that the law curriculum needs to be decolonised, Africanised and transformed so that it addresses and solves the problems of the society it serves. The law curriculum should relate to the African experience and the societal needs. It needs to relate to the needs and the realities of the students and the society at large and not just a small part of the society, because a compromised law curriculum results in a compromised country. This can be done through changing the content of the law curriculum, changing how the curriculum is taught and epistemological decolonisation of the curriculum. If this is done, the vision of building a better country that serves all its citizens and advances them, will be fulfilled. 